Published online: 30 October 2019

\title{
Author Correction: De novo phased assembly of the Vitis riparia grape genome
}

\section{Nabil Girollet, Bernadette Rubio, Céline Lopez-Roques, Sophie Valière, Nathalie Ollat \& Pierre-François Bert}

Correction to: Scientific Data https://doi.org/10.1038/s41597-019-0133-3, published online 19 July 2019

Following publication it was found that co-authors Céline Lopez-Roques, Sophie Valière and Nathalie Ollat were mistakenly omitted from the authorship of this Data Descriptor. The omitted names of these authors, their affiliations, contributions and associated acknowledgements have now been added to both the HTML and PDF versions of the Data Descriptor.

(i) Open Access This article is licensed under a Creative Commons Attribution 4.0 International License, which permits use, sharing, adaptation, distribution and reproduction in any medium or format, as long as you give appropriate credit to the original author(s) and the source, provide a link to the Creative Commons license, and indicate if changes were made. The images or other third party material in this article are included in the article's Creative Commons license, unless indicated otherwise in a credit line to the material. If material is not included in the article's Creative Commons license and your intended use is not permitted by statutory regulation or exceeds the permitted use, you will need to obtain permission directly from the copyright holder. To view a copy of this license, visit http://creativecommons.org/licenses/by/4.0/.

(c) The Author(s) 2019 